\title{
PENERAPAN STRATEGI PEMBELAJARAN LEARNING CELL UNTUK MENINGKATKAN HASIL BELAJAR IPA
}

\author{
Ni Wyn.Nita Kusumayani \\ Jurusan Pendidikan Guru Sekolah Dasar, Fakultas IImu Pendidikan \\ Universitas Pendidikan Ganesha \\ Singaraja,Indonesia \\ e-mail: nitasading90@gmail.com
}

\begin{abstract}
Abstrak
Penelitian ini bertujuan untuk mengetahui peningkatan hasil belajar IPA setelah menerapkan strategi pembelajaran Learning Cell pada siswa kelas IV semester ganjil tahun pelajaran 2016/2017 di SD No. 2 Kapal, Kecamatan Mengwi, Kabupaten Badung. Penelitian ini adalah Penelitian Tindakan Kelas dengan subjek penelitian yaitu siswa kelas IV SD Negeri 2 Kapal tahun pelajaran 2016/2017 yang berjumlah 27 orang. Data penelitian ini tentang hasil belajar pada ranah kognitif, afektif dan psikomotor dikumpulkan dengan menggunakan metode tes dan observasi. Data dianalisis dengan menggunakan analisis deskriptif kuantitatif. Hasil penelitian yang diperoleh yaitu persentase rata-rata hasil belajar pada siklus I 73,70\% yang berada pada kategori sedang dan pada siklus II menjadi $80,19 \%$ yang berada pada kategori tinggi. Ini menunjukan terjadi peningkatan persentase rata-rata hasil belajar siswa dari siklus I ke siklus II sebesar $6,49 \%$. Pada ranah afektif siklus I persentase ratarata sebesar $70,43 \%$ dan pada siklus II sebesar $80,21 \%$ yang berada pada kategori aktif. Pada ranah psikomotor persentase hasil belajar siswa pada siklus I sebesar $71,75 \%$ dan pada siklus II menjadi $80,31 \%$ yang berada pada kategori baik. Dengan demikian dapat disimpulkan bahwa penerapan strategi pembelajaran Learning Cell dapat meningkatkan hasil belajar IPA siswa kelas IV semester ganjil SD No. 2 Kapal Tahun Pelajaran 2016/2017.
\end{abstract}

Kata kunci: Learning Cell, hasil belajar

\begin{abstract}
This study aims to determine the learning outcome natural science after implementing learning strategies Learning Cell in grade IV semester of 2016/2017 academic year in SD No. 2 Kapal, Mengwi, Badung regency. This research is a classroom action research (PTK) with the subject of research that fourth grade students of SD Negeri 2 Kapal in the academic year 2016/2017, amounting to 27 people. This research data on learning outcomes in the cognitive, affective and psychomotor collected using tests and observation. Data were analyzed using quantitative descriptive analysis. The results obtained are the average percentage of learning outcomes in the first cycle of $73.70 \%$ which are in the medium category and the second cycle be $80.19 \%$ which is at the high category. This shows an increase in the average percentage of student learning outcomes from the first cycle to the second cycle of $6.49 \%$. In the first cycle affective average percentage of $70.43 \%$ and the second cycle of $80.21 \%$ which are in the active category. In psychomotor percentage of student learning outcomes in the first cycle of $71.75 \%$ and the second cycle be $80.31 \%$ which are in both categories. It can be concluded that the application of learning strategies Learning Cell can improve learning outcomes natural science grade IV semester of SD No. 2 Kapal in the academic year 2016/2017.
\end{abstract}

Key words: Learning Cell, learning outcomes

\section{PENDAHULUAN}

Pendidikan merupakan salah satu aspek kehidupan yang sangat penting peranannya dalam upaya membina dan membentuk manusia yang berkualitas agar sanggup menghadapi perubahan-perubahan keadaan dalam kehidupan dunia yang senantiasa berubah. Untuk meningkatkan kualitas pendidikan diperlukan suatu upaya yang dilakukan oleh semua komponen dalam dunia pendidikan baik masyarakat maupun dari pemerintah. Pendidikan dikatakan berkualitas jika ditunjang oleh sumber daya manusia yang berkualitas, strategi pembelajaran yang optimal, serta didukung 
oleh prasarana dan dana yang memadai. Proses pembelajaran berlangsung lebih efektif jika semua komponen tersebut bisa saling melengkapi (Depdikbud,1993).

Penyelenggaraan pendidikan dinyatakan sebagai suatu proses pembudayaan dan pemberdayaan peserta didik yang berlangsung sepanjang hayat, dimana dalam proses tersebut harus ada pendidik yang memberikan teladan dan mampu membangun kemauan, serta mengembangkan potensi dan kreativitas peserta didik. Prinsip tersebut menyebabkan adanya pergeseran proses pendidikan, dari pengajaran ke pembelajaran. Proses pembelajaran pada satuan pendidikan hendaknya dilaksanakan secara interaktif, inspiratif, menyenangkan, menantang, memotivasi peserta didik untuk berpartisipasi aktif, serta memberikan ruang yang cukup bagi prakarsa, kreativitas dan kemandirian sesuai dengan bakat, minat dan perkembangan fisik serta psikologis peserta didik. Tugas dan peran guru bukan lagi sebagai pemberi informasi tetapi sebagai pendorong belajar agar siswa dapat mengkonstruksi sendiri pengetahuan melalui berbagai aktivitas belajar. Proses pendidikan tidak terlepas dari kegiatan belajar mengajar di kelas. Pada proses pembelajaran di kelas dihendaki adanya pencapaian hasil belajar maksimal oleh siswa pada bidang studi apapun. Banyaknya tuntutan bidang studi yang harus dipelajari oleh siswa menyebabkan tidak semua bidang studi dikuasai dengan baik. Bidang studi IImu Pengetahuan Alam (IPA) di kelas IV SD No. 2 Kapal rata-rata belum bisa dikuasai oleh siswa sehingga pencapaian hasil belajar maksimal oleh siswa belum tercapai.

Proses pembelajaran IPA di kelas IV SD No. 2 Kapal dengan menggunakan Kurikulum Tingkat Satuan Pendidikan (KTSP) pada awal semester ganjil tahun pelajaran 2016/2017 masih ditemui beberapa permasalahan. Masalah tersebut antara lain: sulitnya memberikan pemahaman tentang suatu konsep baru kepada siswa dan materi dalam IPA merupakan hafalan sehingga sulit menyampaikan materi tersebut kepada siswa. Di sini harus diupayakan suatu cara untuk memberi pemahaman IPA kepada siswa, untuk menarik keinginannya dalam belajar melalui cara-cara yang efektif sehingga materi yang sebagian besar hafalan tidak hanya sekedar dihafal, tapi harus dipahami oleh siswa.

Selama ini, kendala yang sering dijumpai dalam setiap proses pembelajaran adalah dalam mengembangkan strategi pembelajaran yang sesuai dengan tujuan pembelajaran.. Sebagian besar pengajaran masih menggunakan pendekatan pembelajaran yang monoton dan kurang adanya variasi dalam pembelajaran. Pengajaran diberikan melalui metode ceramah tanpa banyak melihat kemungkinan penerapan metode ceramah dengan variasi yang baru. Metode ini banyak dipilih karena ingin mengejar tuntutan kurikulum sehingga dengan waktu yang ada semua materi dapat terselesaikan. Proses pembelajaran yang berpusat pada guru (teacher centered) menyebabkan proses pembelajaran berlangsung satu arah, tanpa memperhatikan interaksi yang terjadi dalam proses pembelajaran antara siswa dengan guru.

Permasalahan lain yang juga terjadi di kelas IV SD No. 2 Kapal adalah hasil belajar yang masih di bawah rata-rata. Acuan yang telah ditetapkan oleh sekolah sebagai target minimal pencapaian hasil belajar belum sepenuhnya mencapai apa yang diharapkan. Nilai Tes Tengah Semester I pada mata pelajaran IPA belum mencapai rata-rata hasil belajar yang diharapkan yaitu belum mencapai nilai $\geq 80$. Rata-rata hasil belajar siswa dari ranah kognitif baru mencapai 69,63 . Selain hasil belajar yang dilihat dari ranah kognitif, dilihat dari ranah afektif dan psikomotor juga masih belum maksimal. Ini dibuktikan dengan sikap siswa yang tidak mau terbuka kepada guru atas materi yang belum mereka kuasai dan minimnya interaksi pembelajaran yang terjadi di kelas.

$\begin{array}{lcr} & \text { Permasalahan } & \text { tersebut dapat } \\ \text { diatasi } & \text { dengan } & \text { menerapkan } \\ \text { pembelajaran } & \text { kooperatif. } & \text { Model }\end{array}$ pembelajaran kooperatif merupakan teknik-teknik kelas praktis yang dapat digunakan guru setiap hari untuk membantu siswa belajar setiap mata pelajaran, mulai dari keterampilan dasar sampai memecahkan masalah yang kompleks (Nur, 2005; Suprijono, 2009; Agustin, dkk, 2013). Pembelajaran kooperatif mengajak peserta didik untuk belajar secara gotong royong dan bekerja sama dalam menyelesaikan 
suatu masalah, hal ini akan lebih meningkatkan interaksi antar sesama dan membantu peserta didik untuk membina hubungan sosial yang baik dengan rekannya (Ibrahim, 2000; Slavin 2008; Efriza, dkk, 2013; Kagan, 1992). Menurut Slavin (1995) beberapa kelebihan belajar kooperatif diantaranya, para siswa diberikan kesempatan untuk mendiskusikan masalah, menentukan strategi pemecahannya, dan menghubungkan masalah tersebut dengan masalah-masalah lain yang telah dapat diselesaikan sebelumnya (Suteja, 2007; Lea, 2002).

Salah satu model pembelajaran kooperatif yang efektif untuk mengatasa permasalahan yang ada dalam penelitian ini adalah strategi pembelajaran Learning Cell. Strategi Pembelajaran Learning Cell merupakan salah satu bentuk bentuk belajar yang diharapkan mampu melibatkan siswa secara aktif dalam pembelajaran IPA. Learning Cell membentuk pada suatu bentuk belajar kooperatif dalam bentuk berpasangan, di mana siswa bertanya dan menjawab pertanyaan secara bergantian berdasarkan materi bacaan yang sama. (Istarani, 2012; Suprijono, 2012

Melalui Strategi Pembelajaran Learning Cell, guru mampu mengarahkan siswa untuk membuat pertanyaan sesuai dengan materi pelajaran yang dipelajarinya dan menunjuk siswa lain secara acak untuk menjawab pertanyaan tersebut. Siswa yang berhasil menjawab berhak diberikan reward oleh guru, sehingga memancing keinginan siswa lain untuk berusaha menjawab. Strategi ini efektif dalam pembelajaran IPA sehingga apa yang menjadi permasalahan siswa dalam pembelajaran dapat diketahui guru (Zaini, 2008)

Beberapa keunggulan dari Strategi Pembelajaran Learning Cell. Diantaranya siswa lebih siap dalam menghadapi materi yang akan dipelajari karena siswa telah memiliki informasi materi yang akan dipelajari melalui berbagai sumber diantaranya buku, internet, guru dan orang yang ahli di bidang materi tersebut.Siswa akan memiliki kepercayaan diri dalam pembelajaran karena pembelajaran ini menggunakan teman sebaya dalam proses pembelajarannya. Siswa yang ditutori tidak akan segan-segan dalam memberikan pertanyaan yang tidak dipahami. Sebaliknya bagi siswa tutor selain pengetahuannya bertambah, kemampuan dalam mengkomunikasikan ilmu pengetahuan pada teman sebaya meningkat Siswa aktif dalam pembelajaran baik sebelum dan sesudah pembelajaran itu sendiri maupun pada saat pembelajaran. Hal itu terjadi karena siswa diberi panduan untuk mencari materi sendiri pada saat setelah atau sebelum pembelajaran dari berbagai sumber, sedang pada saat pembelajaran siswa yang menjelaskan kembali materi yang diperoleh kepada siswa. Kemandirian siswa dalam proses pembelajaran sangat besar karena siswa dituntut memperoleh informasi sebelum dan setelah pembelajaran kemudian mengkomunikasikan kembali materi yang diperoleh pada siswa lainnya pada saat pembelajaran berlangsun. Hubungan sosial siswa semakin baik, antara siswa dengan siswa, siswa dengan guru dan siswa dengan orang lainnya. Dalam kelas berorientasi pada siswa, tiap siswa merupakan seorang siswa sekaligus pengajar.

Strategi pembelajaran Learning Cell ini merupakan cara praktis untuk mengadakan pengajaran siswa di kelas. Teknik pembelajaran ini juga memungkinkan guru untuk tambahan bila dirasa perlu pada pengajaran yang dilakukan oleh siswa.Proses mempelajari hal baru akan lebih efektif jika siswa dalam kondisi aktif. Salah satu cara untuk menciptakan kondisi pembelajaran seperti ini adalah dengan menstimulir siswa untuk menyelidiki atau mempelajari sendiri materi pelajarannya. Teknik sederhana ini menstimulasi pertanyaan yang mana merupakan kunci belajar. Membentuk pasangan belajar diantara siswa merupakan cara efektif untuk mendapatkan pasangan yang bisa dipercaya dalam kegiatan berpasangan dan menempa kemampuan menyimak suatu pendapat, bermasyarakat dan meta kognisi. 
Penerapan strategi pembelajaran Learning Cell selama ini telah diteliti secara empiris oleh peneliti Febriyanti, dkk., 2016). Hasil penelitiannya menyatakan bahwa dengan diterapkan strategi pembelajaran The Learning Cell pada siswa kelas IV SD N Pengkok 1 Kedawung Sragen Tahun Ajaran 2012/2013 terjadi peningkatan dari tiap indikator kemampuan bertanya dari Tahap Pra Siklus hingga Tahap Siklus II. Ini telah membuktikan bahwa Strategi Pembelajaran Learning Cell yang diterapkan oleh Isti pada siswa kelas IV SD N Pengkok 1 Kedawung Sragen Tahun Ajaran 2012/2013 dapat meningkatkan kemampuan bertanya pada siswa. Peneliti lain yang pernah melakukan penelitian ini secara empiris adalah Rini Artika, yang mana hasil penelitiannya menyatakan bahwa dengan diterapkan strategi pembelajaran Learning Cell diperoleh hasil yang memuaskan dengan nilai rata-rata siswa yaitu 77 . Dengan demikian diharapkan juga proses pembelajaran IImu Pengetahuan Alam (IPA) yang menerapkan Strategi Pembelajaran Learning Cell dapat meningkatkan hasil belajar siswa. Berdasarkan dari latar belakang tersebut dapat diupayakan melaksanakan penelitian tindakan kelas dengan judul "Penerapan Strategi Pembelajaran Learning Cell Untuk Meningkatkan Hasil Belajar IImu Pengetahuan Alam (IPA) Siswa Kelas IV Semester Ganjil SD No. 2 Kapal Tahun Pelajaran 2016/2017".

Strategi Pembelajaran Learning Cell merupakan salah satu strategi pembelajaran yang membantu siswa belajar dengan lebih efektif. Learning Cell ini dikembangkan oleh Goldschmid dari Swiss federal Institute of Technology di Lausanne. Learning Cell atau peserta didik berpasangan adalah suatu bentuk belajar kooperatif dalam bentuk berpasangan dimana peserta didik bertanya dan menjawab pertanyaan secara bergantian berdasar pada materi bacaan yang sama. Strategi pembelajaran Learning Cell adalah salah satu cara dari pembelajaran kelompok, khususnya kelompok kecil. Dalam pembelajaran ini siswa diatur berpasangan-pasangan. Salah satu di antaranya berperan sebagai tutor, fasilitator/pelatih ataupun konsultan bagi seorang lagi. Orang yang kedua ini berperan sebagai siswa, peserta latihan ataupun seorang yang memerlukanbantuan. Setelah selesai, maka giliran peserta kedua untuk berperan sebagai tutor, fasilitator ataupun pelatih dan peserta pertama menjadi siswa ataupun peserta latihan (Zaini, 2008). Tujuan dari strategi pembelajaran Learning Cell itu sendiri adalah untuk menciptakan suasana belajar yang mendorong siswanya aktif dalam proses belajar mengajar. Hasil belajar adalah segala sesuatu yang menjadi milik siswa sebagai akibat dari kegiatan belajar yang dilakukannya (Juliah, 2004). Menurut Sudjana (2004) hasil belajar adalah kemampuankemampuan yang dimiliki siswa setelah ia menerima pengalaman belajarnya. Untuk memperoleh hasil belajar dilakukan evaluasi atau penilaian yang merupakan tindak lanjut atau cara untuk mengukur tingkat penguasaan siswa terhadap materi yang dipelajarinya. Kemajuan hasil belajar siswa tidak hanya mencakup penguasaan ilmu pengetahuan yang dimilikinya, tetapi juga sikap dan keterampilan. Faktorfaktor yang mempengaruhi hasil dapat digolongkan menjadi dua jenis saja, yaitu faktor internal dan eksternal. Kedua faktor tersebut saling mempengaruhi dalam proses belajar individu sehingga menentukan kualitas hasil belajar.

IPA atau IImu Pengetahuan Alam memegang peranan sangat penting dan alam kehidupan manusia. $\mathrm{Hal}$ ini disebabkan karena kehidupan kita sangat tergantung dari alam, zat terkandung di alam, dan segala jenis gejala yang terjadi di alam. Pembelajaran IPA tidak akan pernah terlepas dari alam atau lingkungan tempat tinggal kita. Akan selalu ada hubungan timbal balik antara lingkungan dengan makhluk hidup yang mendiami lingkungan tersebut.

Menurut Haryono (2013) menyatakan bahwa "Ilmu Pengetahuan Alam (IPA) sebagai disiplin ilmu dan penerapannya dalam masyarakat membuat pendidikan IPA menjadi penting". Disisi lain menurut Maesetio Donosepoetro (dalam Trianto, 2012) menyatakan bahwa IImu Pengetahuan Alam (IPA) sebagai pembelajaran dibangun atas dasar produk ilmiah, 
proses ilmiah, dan sikap ilmiah. Dimana IPA dipandang sebagai proses, sebagai produk, dan sebagai prosedur. Sebagai proses diartikan semua kegiatan ilmiah untuk menyempurnakan pengetahuan tentang alam maupun untuk menemukan pengetahuan baru. Sebagai produk diartikan sebagai bagian hasil proses, berupa pengetahuan yang diajarkan dalam sekolah atau di luar sekolah ataupun bahan bacaan untuk penyebaran atau dissiminasi pengetahuan. Sebagai produser dimaksudkan adalah metodelogi atau cara yang dipakai untuk mengetahui sesuatu (riset pada umumnya) yang lazim disebut metode ilmiah (scientific method).

\section{METODE}

Penelitian yang dilakukan ini tergolong penelitian tindakan kelas (PTK). Subjek penelitian ini adalah siswa kelas IV semester ganjil SD No. 2 Kapal tahun pelajaran 2016/2017 yang berjumlah 27 orang siswa. Adapun objek penelitian ini adalah hasil belajar IPA siswa dengan diterapkannya strategi pembelajaran Learning Cell dalam pengajaran IPA di kelas IV SD No. 2 Kapal yang meliputi aspek kognitif, afektif dan psikomotor. Prosedur kegiatan pada pelaksanaan PTK ini dilaksanakan dalam dua siklus. Adapun pelaksanaannya terdiri dari 4 tahapan yang terdapat dalam Penelitian Tindakan Kelas (PTK), mengacu pada teori yang dikemukakan oleh Arikunto (2015), yaitu: (1) tahap perencanaan tindakan meliputi menyamakan persepsi dan mempersiapkan instrumen yang diperlukan dalam penelitian , (2) tahap pelaksanaan berupa penerapan strategi pembelajaran Learning Cell, (3) tahap observasi/evaluasi dilakukan secara berkesinambungan selama pembelajaran berlangsung dan evaluasi dilaksanakan pada setiap pertemuan, (4) tahap refleksi dilakukan setiap akhir siklus. Adapun rancangan penelitian tindakan kelas yang dilakukan dapat ditunjukkan pada Gambar 1.

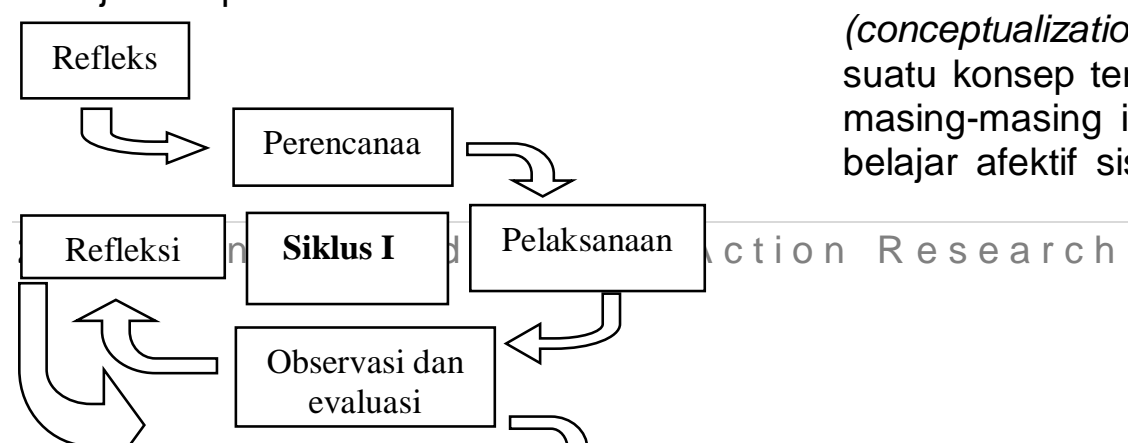
kegiatan tertentu.

\section{Gambar. 1 Bagan Siklus PTK}

(Sumber: Modifikasi riset arikunto:2009)

Metode pengumpulan data yang

digunakan dalam penelitian ini yaitu
metode tes dan metode observasi. Pada

digunakan dalam penelitian ini yaitu
metode tes dan metode observasi. Pada ranah kognitif menggunakan metode tes, sedangkan pada ranah afektif dan psikomotor menggunakan metode observasi dengan menggunakan lembar observasi. Perangkat tes yang digunakan untuk mengukur hasil belajar IPA kelas IV dalam penelitian ini adalah butir-butir soal sesuai dengan topik bahasan yang telah diberikan. Tes ini disusun dalam bentuk pilihan ganda. Tes ini terdiri atas dua puluh butir soal. Sedangkan pada ranah afektif dan psikomotor menggunakan lembar observasi. Penilaian afektif (sikap) siswa tidak bisa dilakukan dengan cara tes, namun penilaiannya dilakukan oleh guru dengan menggunakan lembar observasi afektif. Adapun indikator sikap siswa pada lembar observasi yang peneliti rumuskan sesuai dengan keperluan dalam penelitian ini, yaitu menerima (receiving) yaitu kesediaan menerima hal-hal yang disampaikan oleh orang lain(misalnya oleh guru atau teman). Merespon (responding) yaitu kesediaan untuk memberikan respon terhadap halhal yang disampaikan oleh orang lain. Menghargai(valuing) yaitu kesediaan untuk menghargai suatu nilai, gejala atau

Pembentukan

konsep yaitu penyusunan nilai tertentu. Dari

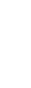


indikator yang masing-masing indikator terdiri dari 4 deskriptor. Penilaian psikomotor(keterampilan) siswa dilakukan oleh guru dengan menggunakan lembar observasi psikomotor. Adapun indikator psikomotor siswa pada lembar observasi yang peneliti rumuskan sesuai dengan keperluan dalam penelitian ini, yaitu ketepatan (accurary) yaitu kemampuan untuk memberikan jawaban secara tepat sesuai apa yang ditanyakan. Pemanfaatan (utilization) yaitu kemampuan untuk menggunakan keterampilan-keterampilan yang dimiliki(baik dalam menjawab atau bertanya). Penyangkutpautan (connection) yaitu kemampuan dalam menghubungkan keterampilan satu dengan yang lainnya. Naturalisasi yaitu kemampuan secara otomatis/tidak kaku. (Nurkancana,1990).

Subjek dalam penelitian ini adalah siswa kelas IV yang berjumlah 27 orang yang terdiri dari 13 orang laki-laki dan 14 orang perempuan, dan objek dalam penelitian ini adalah hasil belajar IPA. Penelitian ini dilaksanakan pada tahun pelajaran 2016/2017 di SD No. 2 Kapal. Teknik analisis data yang digunakan dalam penelitian tindakan kelas ini adalah teknik deskriptif kuantitatif. Tindakan pengolahan data yang dilakukan dengan jalan menyusun secara sistematis dalam bentuk angkaangka dan atau persentase mengenai suatu objek yang diteliti sehingga diperoleh kesimpulan (Agung, 2010). Analisis deskriptif kuantitatif ini digunakan untuk menentukan hasil belajar siswa. Analisisnya dengan cara menghitung rata-rata, angka rata-rata dihitung persentasenya kemudian dikonversikan pada pedoman konversi.

\section{HASIL DAN PEMBAHASAN}

Berdasarkan hasil analisis data nilai pada siklus I diperoleh nilai mean(rata-rata) sebesar 73,70 dan persentase mean $73,70 \%$ artinya dari 27 siswa sebanyak 19 siswa yang nilainya sudah tuntas dan 8 siswa yang nilainya belum tuntas. Pada siklus I terjadi peningkatan nilai hasil belajar dari nilai refleksi awal yaitu dari rata-rata prestasi belajar 69,63 menjadi 73,70. Jika dibandingkan dengan kriteria ketuntasan minimal(KKM) yang ditetapkan oleh SD No. 2 Kapal untuk mata pelajaran IPA yaitu 74 dan persentase mean $\geq 80$ maka hasil belajar siswa pada siklus I belum memenuhi kriteria ketuntasan yang ditetapkan oleh SD No. 2 Kapal. Hal ini berarti bahwa pelaksanaan tindakan pada siklus I belum berhasil. Oleh karena itu, maka penelitian tindakan ini perlu dilanjutkan untuk memperbaiki hasil yang telah dicapai pada siklus I melalui berbagai penyempurnaan pada pelaksanaan siklus II.

Berdasarkan hasil analisis data pada siklus II diperoleh nilai rata-rata sebesar 80,19 dan persentase mean $80,19 \%$ artinya dari 27 siswa sebanyak 21 siswa yang nilainya sudah tuntas dan 6 siswa yang nilainya belum tuntas. Jika dibandingkan dengan kriteria ketuntasan yang ditetapkan oleh SD No. 2 Kapal untuk mata pelajaran IPA yaitu rata-rata skor prestasi belajar $\geq 80$, maka prestasi belajar siswa pada siklus II sudah memenuhi kriteria ketuntasan yang ditetapkan oleh SD No. 2 Kapal. Persentase rata-rata hasil belajar ranah afektif siswa pada siklus 1 adalah $70,43 \%$. Skor rata-rata persen hasil belajar ranah afektif siswa siswa dikonversi ke dalam PAP skala sesuai dengan pedoman konversi PAP skala lima tentang hasil belajar ranah afektif siswa siswa IPA, skor rata-rata persen hasil belajar ranah afektif siswa dalam kategori cukup aktif. skor rata-rata persen hasil belajar ranah afektif siswa siswa pada siklus II adalah 80,21\%. Skor rata-rata persen hasil belajar ranah afektif siswa siswa dikonversi ke dalam PAP skala sesuai dengan pedoman konversi PAP skala lima tentang hasil belajar ranah afektif siswa siswa IPA, skor rata-rata persen hasil belajar ranah afektif siswa dalam kategori aktif. skor rata-rata persen hasil belajar ranah psikomotor siswa siswa pada siklus I adalah $71,75 \%$. Skor rata-rata persen hasil belajar ranah psikomotor siswa siswa dikonversi ke dalam PAP skala sesuai dengan pedoman konversi PAP skala lima tentang hasil belajar ranah 
psikomotor siswa siswa IPA, skor ratarata persen hasil belajar ranah psikomotor siswa dalam kategori cukup baik. skor rata-rata persen hasil belajar ranah psikomotor siswa siswa pada siklus II adalah 80,31\%. Skor rata-rata persen hasil belajar ranah psikomotor siswa siswa dikonversi ke dalam PAP skala sesuai dengan pedoman konversi PAP skala lima tentang hasil belajar ranah psikomotor siswa siswa IPA, skor rata-rata persen hasil belajar ranah psikomotor siswa dalam kategori baik.

Secara umum, hasil belajar siswa mengalami peningkatan pada tiap siklus, baik pada ranah kognitif, afektif dan psikomotor. Peningkatan hasil belajar IPA siswa dari ranah kognitif, afektif dan psikomotor merupakan sebagai dampak dari diterapkannya strategi pembelajaran Learning Cell yang dapat meningkatkan rasa percaya diri siswa dalam bertanya, menjawab maupun dalam mengerjakan soal-soal IPA. Hal tersebut tidak terlepas dari latihan-latihan dan bimbingan yang intensif yang diberikan oleh guru dalam menekankan konsep dasar IPA. Semakin intensif latihan yang diberikan, maka akan semakin meningkat pula pemahaman siswa akan konsep-konsep IPA.

Keberhasilan

strategi

pembelajaran Learning Cell tidak terlepas dari upaya guru dalam membimbing, mengarahkan siswa dalam mempraktikan secara langsung strategi pembelajaran tersebut. Pengawasan yang dilakukan oleh guru dalam pelaksanaan proses pembelajaran sangat berpengaruh terhadap konsentrasi siswa dalam menyelesaikan latihan-latihan yang diberikan.

Sesuai dengan penelitian yang telah dilakukan oleh Isti Dwi Rahmawati dan Dewi Fitria Sani yang menyatakan keberhasilannya dalam menerapkan strategi pembelajaran Learning Cell, peneliti juga mendapatkan hasil yang baik dengan menerapkan strategi pembelajaran yang sama. Berdasarkan paparan diatas, dengan strategi pembelajaran Learning Cell memberikan hasil yang positif dalam meningkatkan hasil belajar siswa baik dari ranah kognitif, afektif dan psikomotor. Ini berarti hipotesis yang diajukan peneliti yaitu "Melalui penerapan strategi pembelajaran Learning Cell dapat meningkatkan hasil belajar IPA siswa kelas IV semester ganjil SD No. 2 Kapal tahun pelajaran 2016/2017 " dapat diterima.

\section{SIMPULAN DAN SARAN}

Berdasarkan hasil penelitian dan pembahasan yang telah diuraikan pada bab sebelumnya, dapat disimpulkan bahwa penerapan strategi pembelajaran Learning Cell telah meningkatkan hasil belajar IPA siswa pada ranah kognitif siswa kelas IV semester ganjil SD No. 2 Kapal tahun pelajaran 2016/2017. Hal ini dapat dilihat dari tes hasil belajar IPA dari ranah kognitif yaitu rata-rata skor prestasi belajar siswa mengalami peningkatan dari 69,63 pada pra siklus menjadi 73,70 pada siklus I dan mengalami peningkatan pada siklus II menjadi 77,59. Daya serap siswa meningkat sebesar dari $69,63 \%$ pada refleksi awal menjadi $73,70 \%$ pada siklus I dan menjadi $77,59 \%$ pada siklus II. Sedangkan ketuntasan belajar siswa juga meningkat dari $62,96 \%$ pada refleksi awal kemudian 70,37\% pada siklus I, dan meningkat menjadi $77,78 \%$

Hasil belajar IPA siswa pada ranah afektif di kelas IV SD No. 2 Kapal dalam proses pembelajaran terhadap strategi pembelajaran Learning Cell tergolong baik. Hal tersebut terlihat dari skor rata-rata hasil belajar IPA siswa pada ranah afektif yang diperoleh yaitu 10,41. Sedangkan hasil belajar IPA siswa pada ranah psikomotor di kelas IV SD No. 2 Kapal dalam proses pembelajaran terhadap strategi pembelajaran Learning Cell tergolong baik. Hal tersebut terlihat dari skor ratarata hasil belajar IPA siswa pada ranah afektif yang diperoleh yaitu 10,5.

Berdasarkan hasil penelitian ini, disampaikan beberapa saran sebagai berikut. Kepada guru hendaknya dapat melanjutkan penerapan strategi pembelajaran Learning Cell sebagai salah satu strategi untuk meningkatkan partisipasi siswa dalam proses pembelajaran, sehingga dapat meningkatkan hasil belajar siswa secara 
berkelanjutan. Bagi Kepala Sekolah hendaknya mengupayakan dan mendayagunakan guru untuk menerapkan strategi pembelajaran Learning Cell dan memfasilitasi media pembelajaran yang memadai. Bagi Peneliti hendaknya memperhatikan hasil penelitian ini sebagai acuan penelitian yang akan dilakukan.

\section{UCAPAN TERIMAKASIH}

Sebagai rasa syukur melalui kesempatan ini disampaikan terimakasih yang setulus-tulusnya kepada semua pihak yang telah membantu dalam penyusunan ini terutama kepada: Bapak Dr. I Nyoman Jampel, M.Pd., selaku Rektor Universitas Pendidikan Ganesha Singaraja, Ibu Prof. Dr. Ni Ketut Suarni, M.S.,Kon., selaku Dekan Fakultas IImu Pendidikan di Jurusan Pendidikan Guru Sekolah Dasar, Prof. Dr. I Gede Astra Wesnawa, M.Si., selaku ketua pengelola Program SKGJ PGSD Universitas Pendidikan Ganesha Singaraja, Ibu Dra. Desak Putu Parmiti, M.S., selaku Ketua Jurusan PGSD FIP Universitas Pendidikan Ganesha Singaraja, Bapak I Gede Margunayasa, S.Pd.,M.Pd., selaku dosen pembimbing, I Nyoman Jani, S.Pd selaku Kepala SD No. 2 Kapal, serta seluruh siswa kelas IV SD No. 2 Kapal.

\section{DAFTAR PUSTAKA}

Agung, A.A. Gede. 2010. "Penelitian Konvensional (Eksperimental dan Non Eksperimental)". Makalah disajikan dalam Workshop Jurusan Pendidikan Guru Sekolah Dasar FIP Undiksha. Jurusan Pendidikan Guru Sekolah Dasar FIP Undiksha. Singaraja 27 September 2010.

Agustin, Setya \& Aryanto, Sugeng. Antara, Sukma. 2013. The Effect Of Using Numbered Head Together Technique On The Eighth Grade Students' Reading Comprehension Achievement At Smpn 2 Tanggul Jember Jurnal Pancaran. 2 (3). 201-210.
Arikunto, S., 2009. Prosedur Penelitian Suatu Pendekatan Praktik. Edisi Revisi 6. Jakarta : Rineka Cipta

Arikunto, S. (2015). Dasar-dasar evaluasi pendidikan: Edisi ke dua. Jakarta: Bumi Aksara

Artika, Rini. 2013. Pengaruh Model Pembelajaran The Learning Cell (Sel Belajar) terhadap Kemampuan Menemukan Gagasan Utama dalam Artikel oleh Siswa Kelas VII SMP Negeri 1 Tanjungbalai Tahun Pembelajaran 2012/2013.

Depdikbud. 1993. Kamus Besar Bahasa Indonesia. Jakarta : Balai Pustaka

Efriza, Dony \& Mukhaiyar, Radja. D. 2013. The Effect Of Using Numbered Heads Together And Reading Motivation On Students' Reading Comprehension Of Descriptive And Narrative Text Of Smpn 7 Muaro Jambi. Journal English Language Teaching (ELT). 1 (3). 65-74.

Febriyanti, Diya., Yunita Wardianti., Sepriyaningsih. 2016. Pengaruh Strategi The Learning Cell Disertai Crossword Puzzle Terhadap Hasil Belajar Biologi Siswa Kelas $X$ Man 2 Lubuklinggau Tahun Pelajaran 2015/2016

Haryono. (2013). Pembelajaran IPA yang Menarik dan Mengasyikkan. Yogyakarta: Kepel Press

Ibrahim, M, dkk. 2000. Pembelajaran Kooperatif. Surabaya: University Press

Istarani. 2012. 58 Model Pembelajaran. Jakarta : Media Persada

Julia, Brannen. 2004. Memadu Metode Penelitian Kualitatif \& Kuantitatif. Yogyakarta: Pustaka Pelajar

Kagan, Spencer, 1992 Cooperative Learning. San Juan Capistrano, Kagan Cooperative Learning.

Lea, Anita. 2002. Cooperative Learning. Jakarta : PT. Gramedia. 
Nur, Mohamad. 2005 Depdiknas.. Pembelajaran Kooperatif. Jawa Timur:

Nurkancana, Wayan. 1990. Evaluasi Hasil Belajar. Surabaya:Usaha Nasional

Slavin, R.E. 1995. Cooperative Learning. Allyn \& Bacon. A Simon \& Aschuster Company.

Slavin, R.E. 2008. Cooperative Learning (Teori, Riset dan Praktek). Bandung: Nusa Media

Sudjana, Nana. 2004. Dasar-dasar Proses Belajar Mengajar. Bandung :Sinar Baru Algensido Offset.

Suprijono, Agus. 2009. Cooperative Learning Teori \& Aplikasi Paikem. Surabaya: Pustaka Pelajar.

Suprijono, A. 2012. Cooperatif Learning. Yogyakarta: Pustaka Belajar.

Suteja. 2007. Pengaruh Model Pembelajaran Kooperatif terhadap Prestasi Belajar Pendidikan Kewarganegaraan (Studi Eksperimen di SMA N 4 Denpasar). Tesis PP Undiksha.

Trianto. 2012. Model-model Pembelajaran Inovatif-Progresif. Jakarta : Kencana Prenada Media Grup.

Zaini, Hisyam dkk. 2008. Strategi Pembelajaran Aktif. Yogyakarta:CTSD 